much more must be accomplished if museums are to play their part in the educational system; and there should be tho less hesitation in transforming some of the now existing severe and aridly didactic galleries into simplified children's galleries, since our observation is that adults enjoy and benefit from the children's exhibits as much as tho children themselves.

\section{The World Power Conference}

THE annual report of the World Power Conference for 1938, prepared by the Central Office of the World Power Conference, 36 Kingsway, London, W.C.2, has just been issued. There was a meeting of the International Executive Council in Vienna during August 29-September 1, attended by more than a thousand persons from thirty-seven different countries. Tho British Council was officially represented by Sir Harold Hartley and J. M. Kennedy. Tho British delegation numbered ninety-three and was nearly double the size of any other visiting delegation. Approximately two hundred papers were presented at the meeting. It is hoped to publish theso papers and the discussions on them this year in tho Transactions of the World Pouer Conference. A new national committee has been formed for Algeria, and there are now forty national committees. In response to an invitation issued and accepted in 1936, the second Chemical Engineering Congress of the World Power Conference will be held in Berlin in 1940. At the same time and place the third Congress on Large Dams will be held. The questions to be discussed have already been fixed. By invitation of the Swiss National Committee a meeting of the International Executive Committee will be held in Zurich shortly.

\section{"Micro-entomology" at Stanford University}

WE have recoived several parts of the journal entitled "Microentomology: Contributions to En. tomology from tho Natural History Museum of Stanford University". This periodical is now in its fourth volume, and it only publishes papers emanating from the Museum just named. The text is from manuscript expressly typed by the Stanford University Press and reproduced by the photolith method. This type of publication has been adopted as a partial solution of the prevailing high costs of printing by monotype and hand-set type. The reproduction has been admirably carried out, but the main factor in the process is the perfect typing of the copy, since the method affords little or no opportunity for errors and corrections. Among the papers published in this journal is a series of articles on the Coccide by G. F. Ferris and collaborators. These are well and clearly illustrated and, in fact, illustrations form the notable feature of this publication, the saving on printing costs allowing for an unusually largo number.

\section{New Seismological Observatory}

IT is learned from Earthquake Notes (10, No. 4, April 1939), published by the Eastern Section of the Seismological Society of America, that a new seismo- logical station is soon to be established at Bogotá, Colombia, South America. It will be at a height of some 2,800 m. above sea-level in the Northern Andes, and will thus be one of the highest in the world. This is made possible by a grant from the Carnegie Corporation of New York to the Jesuit Seismological Association, and the director of the station is J. Emilio Ramírez, S.J., of St. Louis University. The new station will fill a very noticeable gap in the map of seismological observatories, and will supply a definitely seismic area with important observational facilities.

\section{The Lister Institute of Preventive Medicine}

THe annual general meeting of the Lister Institute of Preventive Medicine was held on June 16 when the governing body presented the Institute's forty fifth report. This contains a survey of the Institute's activities, with financial statement and the staff changes, during 1938, and a summary of the research work pursued. Studies on viruses are prominent, and Dr. Eagles has investigated a possible virus factor in the causation of acuto rheumatism. Serological investigations include further work by Dr. Felix on the antigenic structure of the typhoid bacillus and on the standardization of therapeutic anti-typhoid serum, and a study by Dr. Muriel Robertson on the immune reactions in vitro of certain ciliate Protozoa. The nutritional value of buckwheat and its sensitizing action to light has been studied by Dr. Chick, and the results suggest that the nutritive value of the proteins of wheat are inferior to those of buckwheat. The National Collection of Type Cultures of Microorganisms is housed at the Institute, and during the year some 6,300 cultures have been distributed, and many new strains deposited for maintenance.

\section{National Baby Week}

Tre National Baby Week Council (117 Piccadilly, London, W.1) announces that 'National Baby Week' will be celebrated during July 1-7. Propaganda this year will be concentrated on "Fathereraft in the Child Welfare Movement", and the "William Hardt" challenge shield is offered for competition among senior girls in public elementary schools studying infant care. Full particulars may be obtained from the Secretary.

\section{International Exhibition of the Art of Greater India}

The Royal Academy, in collaboration with a number of connoisseurs of Indian art, is arranging to hold in January-March, 1940, an International Exhibition of the Art of the Indian Empire, French Indo-China, Netherlands, India, Burma, Malaya, Siam, Afghanistan, Tibet and Nepal. It is believed that the museums and private collections of those European powers most closely connected with the regions of Indian influence can furnish an exhibition of surprising interest and value, which would servo as a prelude to an exhibition of Indian art, drawn mainly from collections in Asia, to be considered when more settled conditions give a reasonable

(Continued on page 29) 